Vol. 5, No. 1, 2018

UDC 657. 1:658.041

\author{
H. Ronek \\ Doktor, Professor \\ Maria Curie-Sklodowska University (Poland)
}

O. Lemishovska

$\mathrm{PhD}$ in Economics, Associate Professor

Lviv Polytechnic National University

\title{
FINANCIAL STATEMENTS UNDER THE ECONOMY GLOBALIZATION CONDITIONS: CONDITIONS AND PERSPECTIVES OF THE DEVELOPMENT
}

\begin{abstract}
The key issues are described of the current information field of the public financial statements of modern corporate companies in the context of its functions with regard to the information insurance of different users under the conditions of the global post-industrial economy. The assessment was conducted of the methodological aspects of accounting of separate objects of the modern corporations' public accounting. The key aspects are provided of the negative impact of the restricted information of the financial statements of transnational and socially important national companies and the processes of management and regulation of the national and global economy.

The suggested perspectives are analyzed in the theory and world business practice of the development of conceptual grounds for the solution of problem of the adaptation of the format of public statements system of the corporations to the modern economic conditions and informational needs of different groups of users, including the market institutional formations. The need was accentuated of the improvement of accounting approach and principles of presentation of the value of modern corporations' capital. Certain aspects of the development of current basic financial statements fundamentals are justified and suggested.
\end{abstract}

Key words: financial statements, system of indexes, theories, paradigms, adaptation, cost criteria.

\section{Introduction}

Under the conditions of modern globalised economic area any business entity, regardless of its belonging to the specified national economy, functions within the established world financial and economic architecture, complying with the elaborated principles of business, standards of the information and communication technologies. In this context the special meaning is given to the information provided in the public statements by the market economy subjects which develops the efficiency of their functioning, development potential, investment attractiveness, business solvency etc. This information is used essentially by the different institutions - state organs of planning, predicting and regulating of the economic processes within certain national economy, institutional formations at the global markets of capital and investments. Quality, relevance and completeness of the information of public financial statements are, first of all, related to the transformational and national socially meaningful companies. Regardless of the importance of the objectiveness and completeness of financial statements indexes, modern rules and principles of its formation are considered incompliant with the real practice of business and the ones which affect the processes of the global economy regulation. In particular, it is assumed that "modern periodical critical phenomena observed in the process of the development of world economy and separate business entities is the 


\section{H. Ronek, O. Lemishovska}

reason and consequence of the information system which, for different reasons, does not provide the stakeholders with the useful and transparent information" [1, p.94]. Therefore, the genesis of functions and conceptions of the public financial statements under the conditions of the postindustrial society requires further investigation.

\section{Problem settlement}

The transparency and disclosure of the objective and unbiased information about the effectiveness of the functioning, financial and economic condition and development potential is the basis of the corporate management in the modern global economy. The users' requirements are determinant with regard to the information quality characteristics, as to insure the needs of the external users the statement is formed which should have the characteristics of quality, complex characteristics of which is the key attribute of the public financial statements of the corporations. However, "the use of the traditional financial statements package as a resource of information under modern conditions of the world economy is not enough" [2, p.17].

In the scholarly researches of purely topical direction with regard to the development and adaptation of the financial statements to the modern business conditions the "the complex scholarly researches are absent which could tackle the most important issues in the sphere of the accounting statements and would determine the key tendencies of its further development with regard to the transformation of economic conditions of the companies functioning, change of the management approaches, wide application of the information and computer systems and technologies" [3, p.5]. Analysis of the accounting or balance theories which constituted the theoretical grounds of the accounting science development till the beginning of XX cent. (for instance. V.P. Filios [4], gives the reasons to claim the necessity of the development of modern theories of the accounting which would allow explaining the reasons and ground the introduction of the new types of the statements into the accounting practice of modern companies under the globalization conditions and economy post- industrialization. One of the approaches of the assessment of the statements modern paradigm compliance is the specification of the restrictions hindering its further development. The detailed list of such restrictions was determined by the representatives of the Institute of Chartered Accountants in England and Wales based on the analysis of 11 new statement patterns based on which a new approach was suggested to the details and procedural aspects of functioning of the account reports system [5, p.15].

The general issues settlement is about the "theorization of the issues of formation, compilation and publication of the statements for the purpose of searching the possibilities of building the predictions of its further development which will facilitate the improvement of the adaptation of the company accounting systems to the functioning under the new socio-economic conditions" [3, p.10].

Analysis of the last researches and publications testifies to the existing acute problems as to the objectiveness of the information provided in the public financial statement of transnational and socially important corporations, in particular, about the value of assets and capital available. The problematic is first of all related to the type of financial instruments - assets of the virtual economy, specific (virtual) nature of which requires the application of other approaches to their acknowledgement and assessment than the traditional cost-based pattern. Generally characterizing the problematic nature of information in the public statements of modern corporations, Ya. V. Sokolov said: "main task of its adaptation to the modern economic conditions is reduced to the fact that the actual owners (current owners) and especially potential (possible) owners of the shares and other securities have a real idea about the assets of companies which they either want to sell (actual owners) or consider possible to buy (potential owners)" [6].

The elaboration of the new principal approaches and methodological foundations of the public financial statements of the corporate companies is considered by the scholars also in 
wider spectrum than the relations between the corporations and its shareholders. Thus, for instance, V.M. Zhuk justifiably proves the importance of the information of public financial statements of the corporations (for instance, the transnational) on the regulation of the global economic processes: "important grounds of "virtual bubbles" threatening the world economy are the marginal predictions and expectations which could be balanced by the financial statements" [7]. A group of authors of the monograph [8] comes to the conclusion that the "economic transformations under the influence of market mechanism require the new guides in the formation of the financial information transparency level adequate to the global environment" [8, p.193].

Generally, the theoreticians and practitioners acknowledge that the formulation of the new format of institutional environment of correcting the essence of the formal and informal institutions need the essential adaptation to these modifications of the financial statements as an important component of information and analytical instrumentation of management and regulation of the financial and economic processes. The orientation of such adaptation is considered by scholars in different perspectives, in particular, L.M. Pylypenko considers the "key demands to the change of conceptually-methodological foundations of accounting system the approach of the balance statement of the market economy subject to its market value, insurance of the possibility of assessing the efficiency of its functioning according to the created value criterion" [9, p.24].

Such mainstream of the adaptation of modern format of financial statements to the needs of the inter-corporation management, capital markets and investments is dominating. Thus, for instance M.V. Koriahin grounds that "reflection of the indexes of value in the financial statements turns it into the important information resource for the analysis of internal capital management mechanisms, assessment of the efficiency of the use of the invested resources, determination of the level of received added value on the invested capital which constitutes the key interest for the company shareholders and its potential investors" [2, p.266]. Formation of the post-industrial economy conditions-adaptive public accounting of the transnational and socially important national corporations is considered by the scholars also through the possibility of the development of existing principles and approaches to making the financial statements, in particular, in the complementing of its traditional forms by the additional indexes of the financial and non-financial nature about the factors influencing the informational disclosure of the business value. Therefore, according to $\mathrm{T}$. Kurchenko, "new philosophy of assessing the results of the modern companies activity is aimed at the integration of the financial and nonfinancial indexes which also characterize their social and ecological policy, and rendering the information as to all the resources facilitating the receipt of the economic benefits" [1, p.103].

Despite the theoretical grounding by the scholars of different format and configuration of such type of indexes, the methodological range as to their affirmation has not been developed till this day even in the theory. For such purposes it is suggested to use the accounting normalization and transformation methods. However, the first one does not provide for the considering of separate generating assets which may have an essential impact upon the cash flow formation and market value of the company, and the second one which provides for the data correction for bringing the accounting information to the unified standards, contains some uncertainty - declassification of the statement items and making the corrections therein is a possible way of bringing the statements to the requirements of IFRS / USGAAP / IAS, but commonly accepted standard of the company accounting transfer for the reflection of its monetary condition at the capital and investments market was not elaborated.

\section{The unsolved part of the general problem} is connected with the insufficient ability of modern accounting system standardized according to any version to fully satisfy the informational requests of different groups of users, in particular, the unsolved remain the issues of both the public 


\section{H. Ronek, O. Lemishovska}

accounting and the format of presenting this type of informational product.

The article objective is the research of compliance of the financial statement indexes of modern socially important companies with the informational request of users, determination of the reasons of their incompliance in the context of declared functions of public accounting within the global economy, conducting the assessment of conceptions suggested in modern theory of its adaptation to the conditions of real economy and on this basis formulate the arguments as to the viable perspectives of the financial statements theory development.

\section{Statement of basic material}

The meaning of the indexes of public accounting of modern subjects of the market economy in the management of global financial and economic processes, regulation and prediction of the development of the world and national economies, as well as for the purposes of the intercorporation management, is generally accepted. Widely accepted is also the fact that modern principles of construction and standardized rules of the informational formation in the financial statements do not fully satisfy the demands of the interested users and are not able to objectively describe the financial condition of the economic subject, nor the potential of its development, i.e. represent the actual picture of the investment attractiveness of the modern companies.

Considering the above in the world economic practice and, correspondingly, in the scholarly elaborations the numerous directions and conceptions are suggested of the development of existing theory of financial statements; in the scholarly literature and analytical reviews the analysis of its new types and formats is provided of the representation in the practical activity of certain companies. However, according to the prof. K. Napier, even till this day, there is no unified opinion in the manuals leading for the world accounting community as well as there is no unified opinion as to what the theory of financial statements actually is [10, p. 94].
Absence of the formulated concept of the new format of public accounting adequate for the needs of modern economy is substituted by the use of different type by the systems of actual accounting which, as it is considered, is able to transform the traditional accounting indexes into the cost criteria. Such types of accounting are maintained with the application of the double record method and through certain methods of processing the accounting indexes provide the information about the change of the company market value. In practice, in most cases the accounting services do not keep such accounting and transfer it for reading by the exchanges or assessment specialists. It is understandable that this way different methods are used which looses the element of the comparability of public financial statements indexes of different corporations.

Scholars stick to the approach according to which in the wide sense the accounting report theories strive to provide for the grounds for the application of principles or general notions which will allow disregarding the practice of formation and compilation of the financial statements. Such structure is aimed at the insurance of the consecutive and systematic development of practice, its improvement, understanding, explanation and prediction. The formation of the "conceptual structure may take place inside the accounting or based on using the knowledge of the scholarly domains, such as economy, theories of information, psychology, political theory ir law" [10,p.93]. Conceptually suggested elaborations are aimed at the development of the objective theories focusing on the most important, on the researcher's opinion, object of accounting and reporting (for instance, capital of the modern companies) or elaboration of the methodological theories improving one of the accounting method elements (for instance, assessment) and peculiarities of its relative application or its separate object of accounting and reporting.

In the conceptual basis the accounting standards (SFAC1 "Financial statements objectives for the commercial companies" two top user types were determined - investors and borrowers" [11, p.11]. Besides, the authors of the international 
accounting standards (IAS/IFRS and GAAPUS) gradually acknowledge the investors the determining users of public accounting of the market economy subjects. Considering the specific needs of the investors and creditors with regard to the information, the equity capital should be considered the most important object of the accounting and public reports of the corporations: in public accounting such information is represented by the equity capital resources and the rights of different investors. In this case the fact should be underlined [12], that according to IAS the registered capital of the corporate companies with a many owners is the amount of invested capital (shares issue). This capital is subdivided into the registered capital (nominal or declared value of shares) and the amounts received in excess of the registered capital (in some cases the discount - amounts lower than the registered capital). The second resource of the owners' capital is the undistributed income, i.e. the capital stock - the amount of investments made by the shareholders and undistributed income. This factor is important for modern accounting institutional environment, as the development of the pension funds activity and activity of other institutional investors causes the growth of their impact upon the entrepreneurs, due to which their role as the users of the financial statements grows [13, p.5.]

For the objective assessment of enterprise capital important in the conditions of modern publicly - economic and ecological environment is a provision of capital reserve and insurance sources as possibilities of maintenance and increase the potential that characterizes reproductive ability (possibility) of enterprise [14]. Indicator of the reproductive possibility of capital as one of the characteristics of its cost component can be summarized by the scheme that is shown in Fig. 1

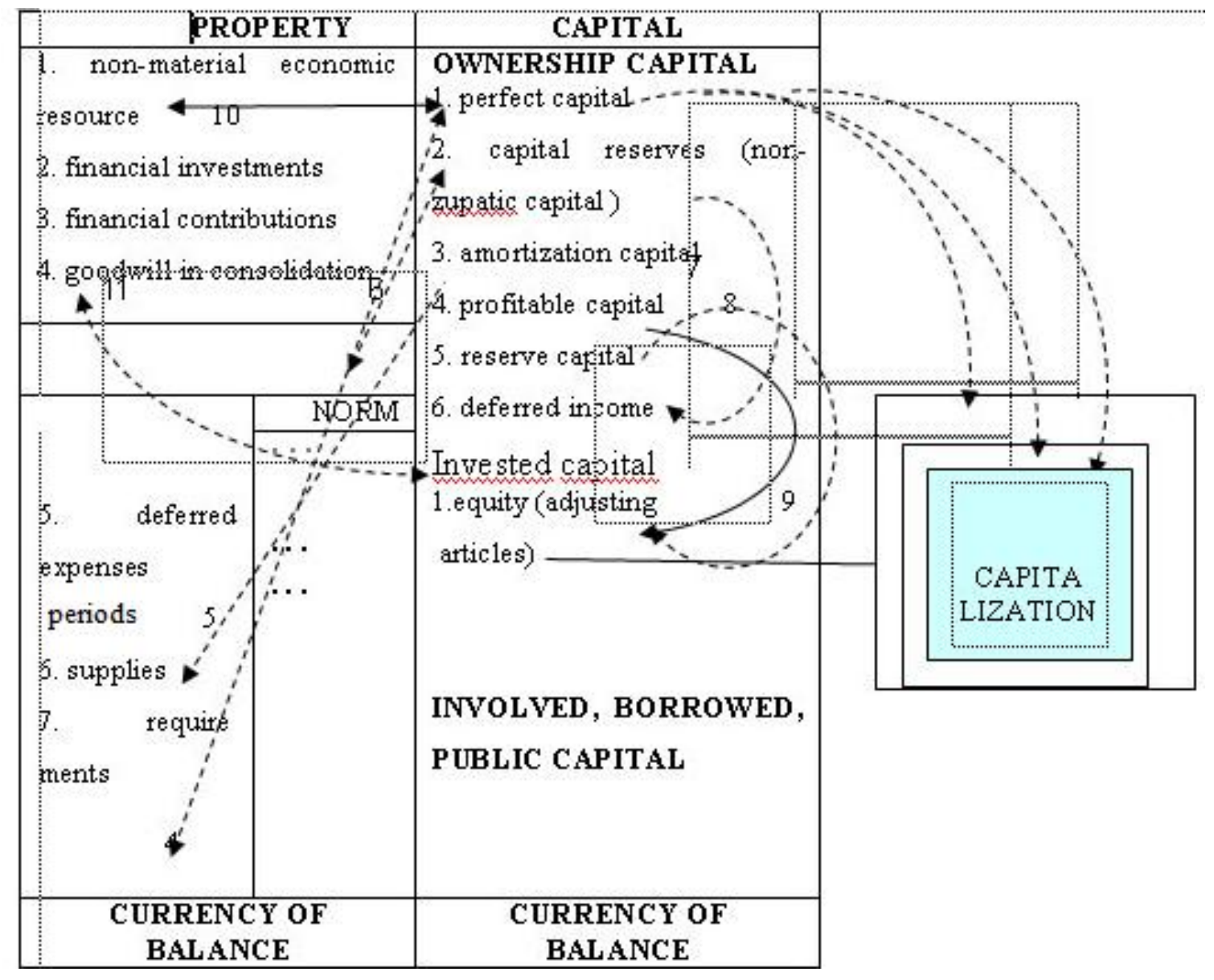

Fig 1. Intercommunication and interdependence of economic resources and constituents of capital for establishment an indicator of reproductive 


\section{H. Ronek, O. Lemishovska}

In this model dependence of market constituent of enterprise capital from assessment of its potential capacity market mechanism is monitored $(1,2,3)$. At the initial public offering, next emissions, in different periods of time the index of boundless constituent of capital changes and on the isometric sum non-material economic resource of enterprise (10) in part of common define and internal corporate goodwill. Interdependence of maximum limit of non-material constituent from the "real" size of enterprises assets was marked by pointer 4 (fair value of the business property).

Pointer 5, which connects the existing enterprise requirements (account receivable) with the creation of appropriate capital reserves as anticipation (expectation of non-payments crisis in conditions of economy stagnant), that should prevent the problems of managing a floating capital.

Capital reserves (pointer 6) should provide abnormal supplies of material values and prepared products, deferred expenses and also to insure doubtful and hopeless account receivable. Such reserves are expedient, in addition, to balance with the size of deferred income, part of which also does not have the proper legal and financial provision (pointer 7). Such revenues in previous periods were included in the calculation of indexes, including indexes that characterize the cost of enterprise. It is suggested (pointer 11) to counterbalance equity with purchased goodwill in consolidation. The offered scheme foresees redemption of fictitious assets that arise up at the fact of purchasing goodwill (extrapolation of results is the overpriced expectations) in a modern economy by reducing the risk of equity losses.

Profit, as an additional cost of invested capital should reflect its direct dependency with the size of market value of this capital (conception of preservation the financial capital) and that is why it must be determined on such basis and meddle with the size of equity in the end of reporting period (pointer 8).

The legislative adjusting of creation the reserve capital should have stricter regulations. Reserve capital that is created according to legislative regulations due to profit, in unprofitable enterprises is absent. Equity remains unprotected in this case, so obviously it needs to increase the protective power of this instrument considered the fundamental and other objects of its creation (base of extra charge) (pointer 9).

The format of financial reporting doesn't mean just a list of items and their groups (sections) placed in different statements. It is a projection of accounting for capital methodology on society information requests. The results of the research [1] have proved that the conceptual model of the format of public postindustrial corporations financial reporting should be based on the emphasis of key criteria, dominant in users information requests (Fig. 2). Such substantiation, taking into account the subject of financial reporting, covers the concept of capital maintenance in its various forms (financial, physical and intellectual) and the theory (paradigm) of capital augmentation - accounting income concepts (accounting interpretation of capital increase from the standpoint of the proprietary, entity, residual equity, enterprise and fund theories). The theoretical basis of financial reporting format is formed, first of all, by the fundamental balance sheet theories (static, dynamic, organic and econometric) and content accounting theories (economic, sociological, ethical, institutional and others).

Essential amount of the equity capital of modern companies is formed by the non-material economic potential. In the financial statements of the majority of translational corporations more than a third of the assets value is related to the nonmaterial (informational and intellectual) economic resources. The problems of acknowledgment, assessment and cost representation of such type of assets in the public accounting of the corporations (first of all of the socially meaningful ones in the global socio-economic environment) are wellknown. Quite obvious is the fact that the existing problematic may not be solved either within the modern accounting theory or on the basis of any standardization versions. The overcoming of the said problem (for instance, quantification of such type of assets - quantitative expression of their qualitative characters for the following measuring stage, i.e. giving the numerical value result) by the national and foreign scholars is viewed in the elaboration of the new institutional accounting and reporting theory which will allow for better development of its methodology. 


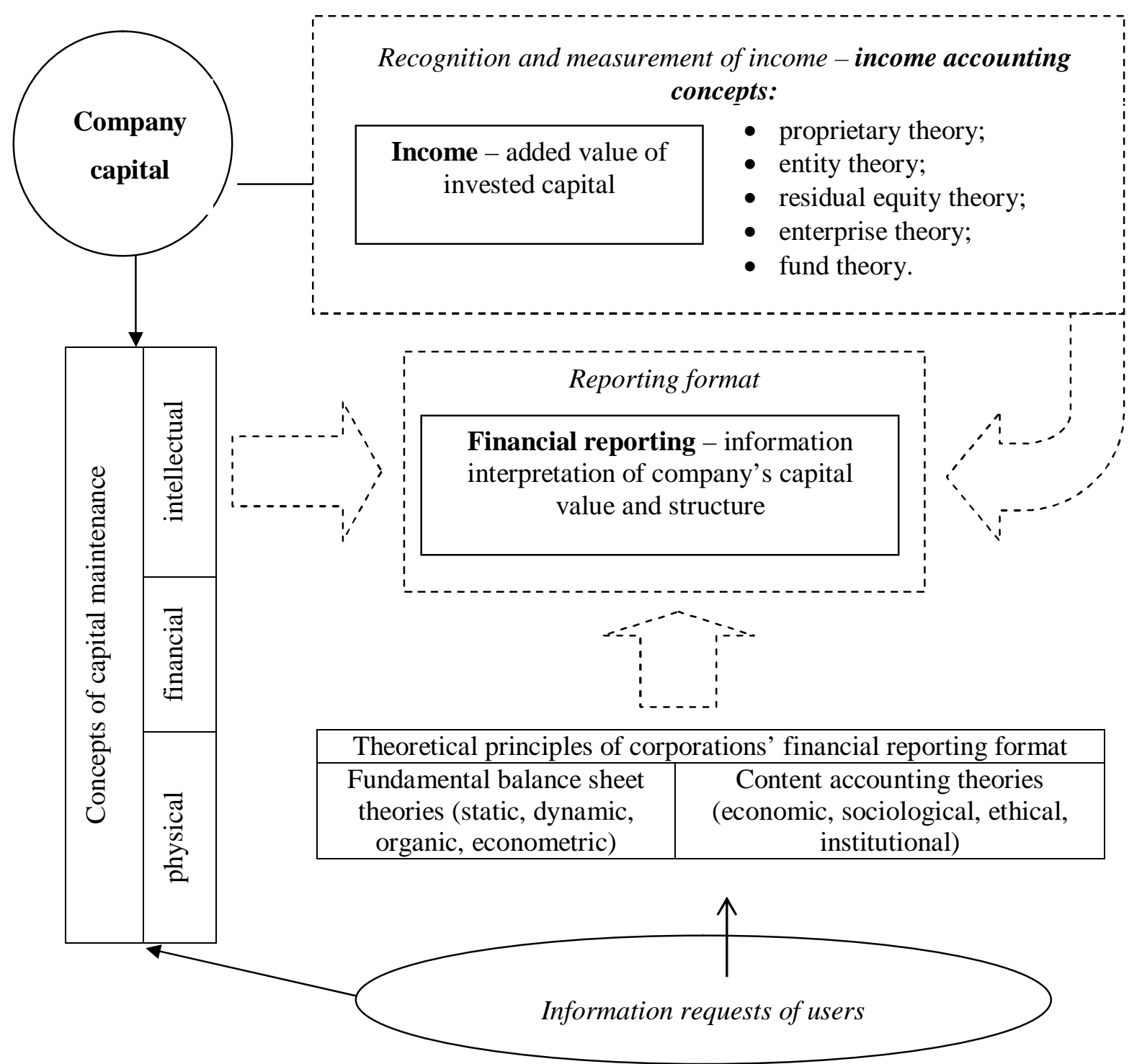

Fig. 2. Conceptual basis of financial reporting format of postindustrial corporations

\section{Conclusions and suggestions of the further investigations}

The mentioned problems as to the condition and possible ways of adaptation of the traditional format of financial statements of the corporations to the modern business conditions, as well as the existing obstacles for the formation of new conceptual and methodological grounds of corporate accounting and, at the same time, acute practical problems in the new type of the formalized indexes are actualized by the research towards the elaboration of the corporations accounting public conception adequate for the modern economy.

\section{References}

1. Pylypenko, L.M. (2016). Rozvytok kontseptsii pobudovy systemy publichnoi zvitnosti korporatsii $v$ umovakh postindustrialnoi ekonomiky [Development of concepts for building a system of public reporting of corporations in a post-industrial economy]. Lviv: Vydavnytstvo Lvivskoi politekhniky. [in Ukrainian]

2. Dankiv, Y.Ya. ed. (2018). Dostupnist finansovoi zvitnosti: novi tendentsii [Availability of Financial Statements: New Trends]. in the monograph "Accounting, analysis, audit, reporting and taxation in the conditions of globalization of the economy". Uzhhorod: Vydavnytstvo UzhNU "Hoverla". [in Ukrainian]

3. Koriahin, M.V. (2012). Bukhhalterskyi oblik u systemi upravlinnia vartistiu pidpryiemstva: teoretyko-metodolohichni kontseptsii [Accounting in the system of management of the value of the enterprise: theoretical and 


\section{H. Ronek, O. Lemishovska}

methodological concepts]. Lviv: Lvivska komertsiina akademiia. [in Ukrainian]

4. Kucherenko, T. (2008) Henezys funktsii i kontseptsii finansovoi zvitnosti $v$ systemi upravlinnia [Genesis of the functions and concepts of financial reporting in the management system], Visnyk TNEU, no 3.pp. 94104. [in Ukrainian]

5. Haidutskyi P.I., Juk V.N. (2012). Rol bukhhalterskoho obliku $v$ poperedzhenni ekonomichnykh kryz. [The role of accounting in preventing economic crises]. Ekonomika Ukrainy, no12, pp. 72-82. [in Ukrainian]

6. Epstein, B.I., Mirza, A.A. (2000). IAS 2000: Interpretation and Aplication of International Accounting Standars. New York: john Wiley Sons Inc.

7. Sokolov, Ya.V. (2000). Osnovy teorii bukhgalterskogo ucheta [Fundamentals of Accounting Theory]. Moscow: Finansy $i$ statistika. [in Russian]

8. Koriahin, M.V., Kutsyk, P.O. (2016). Problemy ta perspektyvy rozvytku bukhhalterskoi zvitnosti [Problems and prospects of the development of inancial statements]. Kyiv: Interservis. [in Ukrainian]

9. Mourik, C., Walton R. (2013). The rout ledge companion to accounting, reporting and regulation. Routledge.

10. Rilios, V.P.(1981). Four Schools of European Accounting Thought. The Accounting Historians jornal, Vol. 8, pp. 61-78.

11. Albrecht, W.S., Sack R. J. (2000). Accounting education: charting the course. American Accounting Association.

12. Statement of Financial Accounting Concepts No. 1 "Objectives of Financial Reporting by Business Enterprises" (1978). Financial Accounting Standards Board.

13. New Reporting Models for Business (2003). Information for Better Markets Initiative. London, ICAEW.

14. Yaremko, I., Zahorodnij, A. (2011). The real cost of capital: approaches and methods. Marketing and logistics problems in the management of organization. Wydawnictwo Akademii TechniznoHumanistycznej w Bielsku-Bialej, pp.283-295. 